\title{
PENGENDALIAN PERSEDIAAN OBAT DENGAN PENDEKATAN ECONOMIC ORDER QUANTITY
}

\author{
Ganda Sirait ${ }^{1 *}$ \\ ${ }^{1}$ Program Studi Teknik Industri, Universitas Putera Batam \\ Jalan R. Soeprapto, Batu Aji Kota Batam Kepulauan Riau \\ *Email: ganda.srt@gmail.com
}

\begin{abstract}
Product inventory in pharmacies is one of problem in controlling drug supplies. How to provide an efficient product, need the right calculation with the right method. EOQ method shows that there are savings on inventory cost. It is expected in this case was to determine a forecast that the drugs inventory_control. The approach used in this study is quantitative descriptive. Source of data in this study using primery data sources obtained directly from the company. Data collection data using documentation and interviews. Data analysis used in this research using Economic Order Quantity. The forcasting results for ordering efficient drugs in 2019 are: first, Amlodipine $5 \mathrm{mg} 10.153$ boxes are needed and at a cost of Rp. 12,843,264.00. Second, Simvastatin $20 \mathrm{mg} 25.288$ boxes are need at the cost of Rp. 30,44,245.00.
\end{abstract}

Keywords: Forecasting, EOQ, and Inventory

\section{Pendahuluan}

Perusahaan industri farmasi merupakan perusahaan yang berkembang dengan pesat, karena mengingat akan kebutuhan manusia yang selalu meningkat. Perkembangan Ilmu Pengetahuan dan Teknologi (IPTEK) membawa pengembangan dan penemuan baru dalam dunia farmasi, sehingga kompetisi antara perusahaan ini semakin serius. Para kompetitor mendorong perusahaan untuk menciptakan produk-produk yang unggul dipasar dan meningkatkan produksi untuk menjaga stock produk tetap ada di pasar. Dalam memenuhi produksi sesuai dengan order pelanggan, maka perlu menetapkan perencanaan dan pengendalian persediaan berdasarkan pesanan.

Persediaan merupakan masalah utama pada semua perusahaan yang berorientasi laba, perusahaan jasa termasuk farmasi. Rumah sakit dan klinik yang menyediakan obat-obatan merupakan perusahaan jasa yang mempunyai permasalahan dengan inventory dan pengendalian produk.

Perusahaan yang harus mengendalikan stock atau persediaan dalam menjalankan operasional seperti Kimia Farma yang berpera sebagai perdistribusian serta penjualan produk-produk pada bidang kesehatan dengan misi perusahaan sebagai distributor utama atau principal pada persediaan obat-obatan. Kimia Farma sebagai distributor memiliki tantangan mewujudkan misi yaitu, mampu menyediakan persediaan obat yang lengkap. Untuk itu perlu dimiliki oleh perusahaan metode bagaimana penerapan merencanakan dan mengendalikan persediaan produk-prosuk, yaitu obat-obatan dengan tepat sesuai kebutuhan konsumen.

Sistem persediaan produk pada Kimia Farma saat ini menggunakan metode analisis $\mathrm{ABC}$, yaitu pengklasifikasian barang berdasarkan peringkat tertinggi sampai terendah. Metode ini belum memberi hasil yang memuaskan karena masih di adanya beberapa kekurangan maupun kelebihan persediaan barang. Hal ini menimbulkan masih besarnya biaya-biaya penyimpanan dan pemelihataan stok obat. Kekurangan stok dapat menganggu kelancaran proses bisnis.

Tujuan penelitian ini adalah untuk mengetahui pengendalian persediaan obat-obatan yang ada di Kimia Farma. Metode yang lebih tepat dalam memberikan solusi dari permasalahan yang ada dalam persediaan. Adapun analisis dalam perencanaan dan pengendalian produk, yaitu metode Economic Order Quantity (EOQ). Metode Economic Order Quantity (EOQ) merupakan sebuah teknik untuk mengendalikan persediaan produk yang bertujuan meminimasi biaya persedian produk atau bahan baku, dengan EOQ dapat menentukan jumlah pemesanan (Order Quantity) utnuk menurunkan jumlah biaya-biaya pemesanan, penyimpanan dan pemeliharaan persediaan bahan, kemudian digunakan juga untuk 
menaksir jadwal order barang yang tepat dimasa yang akan datang. Diharapkan metode EOQ bisa menjadi alternatif bagi perusahaan farmasi khususnya Kimia Farma dalam melaksanakan kegiatan operasional perusahaan yang optimal.

\section{Landasan Teori}

\subsection{Persediaan}

Persediaan (inventory) merupakan barang atahu bahan yang merupakan kekayaan (harta) sebuah prusahaan yang disimpan dalam antisipasi dalam memnuhi permintaan (Amrillah, 2016). Sistem persediaan ini dapat dibedakan menjadi dua dasar, yaitu sistem persediaan ukuran pemesanan tetap dan sistem persediaan interval pemesanan tetap.

\subsection{Pengendalian Persediaan}

Pengendalian persediaan adalah sebagai sesatu aktivitas untuk mengendalikan kuantitas suatu persediaan produk maupun bahan baku, sehingga perusahaan dapat memenuhi permintaan konsumen dan mengetahu kapan dilakukan pemeblian yang tepat (Amrillah, 2016).

\subsection{Perencanaan}

Perencanaan adalah kegiatan menetapkan tujuan, sasaran organisasi dan langkah-langkah kegiatan yang diharapkan akan dicapai (Assauri, 2016: 308). Menetapkan tujuan adalah sebagai dasar membuat langkah-langkah suatu operasional yang terperinci untuk mencapai tujuan yang diinginkan dan mengunakan sumber daya untuk mencapai tujuan tersebut.

\subsection{Peramalan}

Peramalan (forecasting) merupakan suatu teknik dalam analisa perhitungan dengan pendekatan secara kualitatif dan kuantitatif. Peramalan (forecasting) adalah suatu kegiatan yang memprediksi nilai masa depan dengan menganalisis dasar-dasar pengetahuan atau nilai pada masa lalu yang dipersiapkan (Assauri, 2016: 72).

Pola data dari serangkaian data dalam deret waktu (time series) dapat dikelompokkan dalam pola dasar sebagai berikut (Herjanto, 2008: 117):

1. Pola Trend, yaitu jika terdapat kenaikan atau penurunan sekuler jangka panjang dalam data.
2. Pola musiman (Seasonal), yaitu jika polanya merupakan gerakan yang berulang-ulang secara teratur setelah satu periode, misalnya mingguan, bulanan, kuartilan, semesteran, tahunan dan sebagainya.

3. Pola siklus (Cyclical), yaitu jika datanya dipengaruhi oleh fluktuasi ekonomi jangka panjang seperti yang berhubungan dengan siklus bisnis.

4. Pola horizontal, yaitu jika nilai data observasi berfluktuasi disekitar nilai rata-rata yang konstan atau stabil.

\subsection{Pengendalian}

Pengendalian merupakan suatu aktifitas perusahaan yang dilakukan untuk mengetahui sejauh mana kegiatan operasional perusahaan yang dilaksanakan sesuai dengan perencanaan semula (Aulia dan Indrawati, 2014: 4).

\subsection{Metode Economic Order Quantity}

Ekonomis adalah jumlah pemesanan yang disertai dengan jumlah biaya yang_paling rendah. EOQ adalah suatu cara untuk memperoleh sejumlah barang dengan biaya minimum dan adanya pengawasan terhadap biaya pemesanan dan biaya penyimpanan Manullang \& Sinaga (2005: 70). Perlu diketahui, bahwa metode ini merupakan hal yang umum dipakai sebagai teknik pengendalian persediaan.

Perhitungan EOQ adalah sebagai berikut (Usuli, 2013: 50):

$$
E O Q=\sqrt{\frac{2 D S}{H}}
$$

Dimana:

$$
\begin{array}{ll}
\text { EOQ } & \text { Economic Order Quantity (Kuantitas } \\
& \text { pemesanan ekobomis) } \\
\text { S } & =\text { Biaya per pesanan } \\
\text { D } & =\text { Kuantitas penggunaan per periode }
\end{array}
$$

\subsection{Safety Stock}

Menurut Abdurrofi dan Karismariyanti (2016: 62) safety stock adalah persediaan tambahan yang dilakukan untuk melindungi atau mengantisipasi terjadinya kekurangan bahan (stock out). Pentingnya menghitung safety stock karena seringnya terjadi pesanan baru datang setelah waktu tunggu (lead time) terlampaui dan sering terjadi peningkatan produksi. Keadaan ini akan 
berakibat terjadinya stock out yang selanjutnya akan mengganggu proses produksi. Ketika perusahaan mengadakan safety stock hendaknya mempertimbangkan suatu tingkat safety stock yang tidak terlalu besar ataupun tidak terlalu kecil. Karena persediaan yang terlalu besar akan menimbulkan biaya yang besar pula, begitu pula sebaliknya safety stock yang terlalu kecil dikhawatirkan tidak dapat memenuhi fungsinya sebagai cadangan guna menunjang kelancaran proses produksi (Imelda \& Soni, 2011: 102).

\subsection{Reorder Point (ROP)}

Saat dimana harus diadakan pemesanan lagi sedemikian rupa sehingga kedatangannya atau penerimaan barang yang dipesan tepat waktu disebut dengan reorder poin (ROP)t. Reorder point ini harus dilakukan sebelum persediaan barang habis dipakai dalam produksi, perusahaan harus melakukan reorder point yang bermaksud agar pada saat pemesanan datang persediaan barang masih berada atau tepat di atas safety stock (Riyanto, 2001: 83).

Untuk perhitungan reorder point (ROP) dapat digunakan rumus berikut ini (Assauri, 2016: 233):

$$
R O P=(\text { Lead Time } \times Q)
$$

Dimana:

ROP $=$ Titik pemesanan kembali

\section{Metode Penelitian}

Pengumpulan data diperoleh melalui laporan pengadaan data satu tahun terakhir dari bagian pengadaan produk untuk jenis Amlodipine $5 \mathrm{mg}$ dan Simvastatin $20 \mathrm{mg}$. Untuk analisis data dilakukan dengan teknik observasi dan studi literatur. Analisi data menggunakan metode EOQ berdasarkan data historis Amlodipine $5 \mathrm{mg}$ dan simvastatin $20 \mathrm{mg} 2015$ - 2018.

\section{Hasil dan Pembahasan}

Pada tabel 1 dibawah merupakan data yang diperoleh dari perusahaan tentang kebutuhan persediaan obat-obatan selama periode januari sampai desember 2018. Gambar 1 merupakan data historis persediaan obat pada tahun 2018 yang disajikan dalam grafik. Berdasarkan grafik persediaan obat yang memiliki kecenderungan naik setiap bulan.

Tabel 1. Persediaan Obat Tahun 2018

\begin{tabular}{lcc}
\hline \multicolumn{1}{c}{ Bulan } & $\begin{array}{c}\text { Amlodipine 5 } \mathbf{~ m g} \\
\text { Rp. 43.636 per Box }\end{array}$ & $\begin{array}{c}\text { Simvastatin 20 } \mathbf{~ m g} \\
\text { Rp. 46.636 per Box }\end{array}$ \\
\hline Januari & 1,019 & 2,562 \\
Februari & 1,038 & 2,623 \\
Maret & 1,058 & 2,685 \\
April & 1,077 & 2,746 \\
Mei & 1,096 & 2,807 \\
Juni & 1,116 & 2,869 \\
July & 1,135 & 2,930 \\
Agustus & 1,154 & 2,992 \\
September & 1,174 & 3,053 \\
Oktober & 1,193 & 3,115 \\
November & 1,212 & 3,176 \\
Desember & 1,232 & 3,238 \\
\hline & $\mathbf{1 3 , 5 0 4}$ & $\mathbf{3 4 , 7 9 6}$ \\
\hline
\end{tabular}


Data Persedian Obat 2018

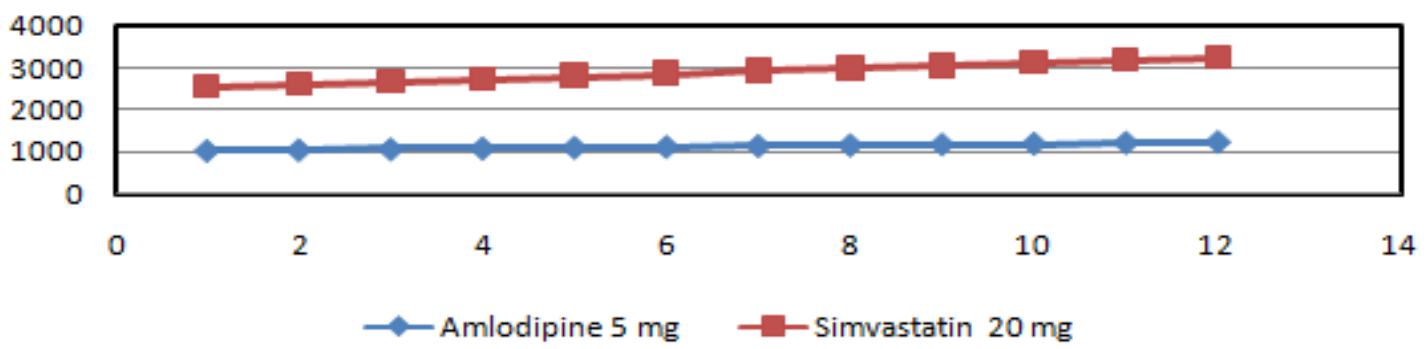

Gambar 1. Data Persedian Obat 2018

Berikut didapatkan hasil perhitungan yang disajikan pada tabel 2. Data yang memiliki pola trend, metode forcasting yang digunakan adalah exponential smoothing with trend. Berikut perhitungan forecasting dengan mengubah alpha dan beta dengan nilai kesalahan tidak terlalu besar.

Tabel 2. Rekapitulasi Perhitungan Forecast Obat Amlodipine $5 \mathrm{mg}$ (Box)

\begin{tabular}{rrrrr}
\hline Periode & Permintaan & $\alpha=0,5 ; \beta=0,3$ & $\alpha=0,6 ; \beta=0,2$ & $\alpha=0,53 ; \beta=0,24$ \\
\hline 1 & $1,019.00$ & & & \\
2 & $1,038.00$ & $1,019.00$ & $1,019.00$ & $1,019.00$ \\
3 & $1,058.00$ & $1,031.35$ & $1,032.68$ & $1,031.48$ \\
4 & $1,077.00$ & $1,051.52$ & $1,053.19$ & $1,051.32$ \\
5 & $1,096.00$ & $1,074.93$ & $1,075.65$ & $1,073.99$ \\
6 & $1,116.00$ & $1,099.30$ & $1,098.48$ & $1,097.51$ \\
7 & $1,135.00$ & $1,123.98$ & $1,121.71$ & $1,121.52$ \\
8 & $1,154.00$ & $1,147.48$ & $1,143.99$ & $1,144.58$ \\
9 & $1,174.00$ & $1,169.71$ & $1,165.51$ & $1,166.69$ \\
10 & $1,193.00$ & $1,191.46$ & $1,187.14$ & $1,188.62$ \\
11 & $1,212.00$ & $1,212.07$ & $1,207.89$ & $1,209.55$ \\
12 & $1,232.00$ & $1,231.87$ & $1,128.09$ & $1,229.77$ \\
\hline
\end{tabular}

\subsection{Analisis Kesalahan}

Dalam melakukan peramalan terjadi ketidaksesuaian antar data actual dengan hasil permalan, maka dilakukan hitung error dengan metode analisis kesalahan MAD, MSE, MAPE dan
CFE. Nilai error terkecil dimiliki dengan nilai $\alpha$ $=0,5$ dan $\beta=0,3$ dengan MAD sebesar 12,0434, MSE sebesar 238,9134, MAPE sebesar 1,1074 dan CFE sebesar 132,3335.

Tabel 3. Rekapitulasi Perhitungan error Pada Persediaan Obat

\begin{tabular}{lrrr}
\hline Perbandingan & $\boldsymbol{\alpha}=\mathbf{0 , 5 ;} \boldsymbol{\beta}=\mathbf{0 , 3}$ & $\boldsymbol{\alpha}=\mathbf{0 , 6} ; \boldsymbol{\beta}=\mathbf{0 , 2}$ & $\boldsymbol{\alpha}=\mathbf{0 , 5 3 ;} \boldsymbol{\beta}=\mathbf{0 , 2 4}$ \\
\hline MSE & 238.9134 & 245.9304 & 263.9542 \\
MAD & 12.0434 & 13.7871 & 13.7243 \\
MAPE & 1.1074 & 1.2517 & 1.2512 \\
CFE & 132.3335 & 151.6584 & 150.9673 \\
\hline
\end{tabular}

\subsection{Hasil Peramalan}

Berdasarkan data pada tabel di atas, dilakukan peramalan dengan Metode Exponential Smoothing with Trend menggunakan $\alpha=0,5$ dan $\beta=0,3$ yang ditampilkan dalam tabel 3 . Hasil metode peramalan terbaik dengan menganalisis MAPE, MAD dan MSE yang disajikan pada tabel 
dibawah. Jenis obat pertama, Amlodipine $5 \mathrm{mg}$ menggunakan persamaan:

$$
\mathrm{Y}=1125,333+9,6713(\mathrm{t})
$$

Jenis obat kedua Persamaan untuk Simvastatin 20 mg menggunakan persamaan:

$$
\mathrm{Y}=2077,083+65,5122(\mathrm{t})
$$

Hasil dari perhitungan peramalan untuk satu periode selama januari sampai desember untuk dua jenis produk dapat ditampilkan seperti pada Tabel 4 berikut ini.

Tabel 4. Hasil Peramalan

\begin{tabular}{lrr|rr}
\hline \multirow{2}{*}{$\mathbf{2 0 1 9}$ Bulan } & \multicolumn{2}{c|}{ Amlodipine 5mg } & \multicolumn{2}{c}{ Simvastatin 20mg } \\
\cline { 2 - 5 } Januari & \multicolumn{1}{c}{ Persediaan } & Peramalan & Persediaan & Peramalan \\
Februari & 1,019 & 1,251 & 2,562 & 2,929 \\
Maret & 1,038 & 1,261 & 2,623 & 2,994 \\
April & 1,058 & 1,270 & 2,685 & 3,060 \\
Mei & 1,077 & 1,280 & 2,746 & 3,125 \\
Juni & 1,096 & 1,290 & 2,807 & 3,191 \\
Juli & 1,116 & 1,299 & 2,869 & 3,256 \\
Agustus & 1,135 & 1,309 & 2,930 & 3,321 \\
September & 1,154 & 1,319 & 2,992 & 3,387 \\
Oktober & 1,174 & 1,328 & 3,053 & 3,453 \\
November & 1,193 & 1,338 & 3,115 & 3,518 \\
Desember & 1,212 & 1,348 & 3,176 & 3,584 \\
\hline Total & 1,232 & 1,357 & 3,238 & 3,649 \\
\hline
\end{tabular}

Perhitungan Economic Order Quantity

Persediaan produk yang ekonomis berdasarkan pada:

Tabel 5. Data Rumusan EOQ

\begin{tabular}{llrr}
\hline \multicolumn{5}{c}{ Tahun 2019 } \\
\hline Jenis Produk & Satuan & \multicolumn{1}{c}{ Amlodipine 5mg } & \multicolumn{1}{c}{ Simvastatin 20mg } \\
\hline Total Kebutuhan & Box & $15,650.00$ & $39,467.00$ \\
Biaya Order & Rp & $4,165,968.00$ & $9,754,509.00$ \\
Biaya Simpan & Rp & $1,265.00$ & $1,204.00$ \\
\hline
\end{tabular}

Besar pembelian obat yang ekonomis berdasarkan tabel 5 diatas dengan menggunakan metode EOQ sebagai berikut:

Jenis Amlodipine 5 mg

$$
\begin{aligned}
\text { EOQ } & =\sqrt{\frac{2 \mathrm{DS}}{\mathrm{H}}} \\
& =\sqrt{\frac{2 \times 15.650 \times 4.165 .968}{1.265}}=10.153
\end{aligned}
$$

$\mathrm{F}=\frac{\mathrm{D}}{\mathrm{Q}}=\frac{15.650}{10.153}=1,541 \approx 2 \mathrm{kali}$

Jenis Simvastatin 20 mg

$$
\mathrm{EOQ}=\sqrt{\frac{2 \mathrm{DS}}{\mathrm{H}}}
$$

$$
\begin{aligned}
& =\sqrt{\frac{2 \times 39.467 \times 9.754 .509}{1.204}}=25.288 \\
& F=\frac{D}{Q}=\frac{39.467}{25.288}=1,561 \approx 2 \text { kali }
\end{aligned}
$$

\subsection{Perhitungan Total Biaya Persediaan}

Sebelum menghitung jumlah biaya persediaan, maka perlu diketahui hal berikut ini: 
Tabel 6. Hasil Total Biaya Persediaan

Tahun 2019

\begin{tabular}{lcc}
\cline { 2 - 3 } Jenis Data & $\begin{array}{l}\text { Amlodipi } \\
\text { ne 5mg }\end{array}$ & $\begin{array}{l}\text { Simvastatin 20 } \\
\text { mg }\end{array}$ \\
\hline $\begin{array}{l}\text { Total } \\
\text { Kebutuhan } \\
\text { (Box) }\end{array}$ & 15.650 & 39.467 \\
$\begin{array}{l}\text { Biaya Pesan } \\
\text { (Rp) }\end{array}$ & 4.165 .968 & 9.754 .509 \\
$\begin{array}{l}\text { Biaya Simpan } \\
\text { (Rp) }\end{array}$ & 1.265 & 1.204 \\
Persediaan & 10.153 & 25.288 \\
Obat & & \\
\hline
\end{tabular}

\section{Amlodipine 5 mg}

$$
\begin{aligned}
\text { TIC } & =\left[\frac{\mathrm{D}}{\mathrm{Q}} \mathrm{S}\right]+\left[\frac{\mathrm{Q}}{2} \mathrm{H}\right] \\
& =\left[\frac{15.650}{10.153} 4.165 .968\right]+\left[\frac{10.153}{2} 1.265\right] \\
& =12.843 .264
\end{aligned}
$$

Biaya Persediaan sebesar Rp 12.843.264

Simvastatin $20 \mathrm{mg}$

$\mathrm{TIC}=\left[\frac{\mathrm{D}}{\mathrm{Q}} \mathrm{S}\right]+\left[\frac{\mathrm{Q}}{2} \mathrm{H}\right]$

$=\left[\frac{39.467}{25.288} 9.754 .509\right]+\left[\frac{25.288}{2} 1.204\right]$

$=30.447 .245$

Biaya Persediaan sebesar Rp 30.447.245

\section{Kesimpulan}

Jumlah pemesanan obat yang ekonomis pada masa yang akan datang tahun 2019 adalah, jenis obat amlodipine $5 \mathrm{mg}$ sebanyak 10.153 kotak dan total biaya persediaan yang dibutuhkan sebesar Rp12.843.264 dan jenis obat Simvastatin $20 \mathrm{mg}$ sebanyak 25.288 kotak dengan total biaya persediaan yang dibutuhkan sebesar Rp30.447.245.

\section{DAFTAR REFERENSI}

Assauri, Sofjan. (2016). Manajemen Operasi Produksi Pencapaian Sasaran Organisasi Berkesinambungan ( ( $^{\text {rd }}$ ed.). Jakarta: Rajawali Pers.

Aulia, F.U., \& Indrawati. (2014). Analisis Perencanaan dan Pengendalian Bahan Baku pada Perusahaan Rokok PAHALAKU
Sampang. Jurnal Manajemen \& Kewirausahaan, 1(17), 1-16.

Azmi Fahmi, Zahroh ZA. \& Maria Goretti NP (2016). Analisis Metode Economic Order Quantity (EOQ) Sebagai Dasar Pengendalian Persediaan Bahan Baku Pembantu. Malang. Jurnal Administrasi Bisnis, 33(1), 35-42.

Herjanto, Eddy. (2008). Manajemen Operasi. Jakarta: Grasindo.

Indrayati, R. (2007). Analisis Pengendalian Persediaan Bahan Baku dengan Metode EOQ (Econopmic Order Quantity) pada PT. Tipota Furnishing Jepara. Semarang: Unsem Siagian, Y. M. (2006). Aplikasi Supply Chain Management dalam Dunia Bisnis. Jakarta: PT. Grasindo.

Usuli, S. (2013). Analisis Economic Order Quantity (EOQ) pada Perusahaan Tahu Tempe VIRA. Jurnal Ilmiah EKOMEN, 13(2), 47-55. Diakses dari 